\title{
An economic analysis of beef cattle fattening in selected areas of Pabna and Sirajgonj Districts
}

\author{
P. K. Sarma ${ }^{1^{*}}$, S. K. Raha ${ }^{2}$ and H. Jørgensen ${ }^{3}$ \\ ${ }^{1}$ Scientific Officer, Bangladesh Agricultural University Research System (BAURES), ${ }^{2}$ Department of Agribusiness and \\ Marketing, Bangladesh Agricultural University, Mymensingh-2202, Bangladesh and ${ }^{3}$ Knowledge Centre for \\ Agriculture, Danish Agricultural Advisory Service (DAAS), Agro Food Park 15 Skejby, DK 8200 Aarhus N, Denmark, \\ *E-mail:sharmapk73@gmail.com
}

\begin{abstract}
This study examined the profitability of beef cattle fattening in the northern char area of Bangladesh. A total of 150 cattle fatteners were randomly selected from two districts representing the highest concentration of fatteners in the char area. Socioeconomic data as well as data on beef fattening were collected from the people selected at Pabna and Sirajgonj district. Descriptive statistics was used to analysis the socioeconomics characteristics of beef producers, the profit function was used to determine the profitability of beef market and regression analysis was used to determine the factor affecting profitability of beef cattle. In spite of beef cattle production was profitable agribusiness most of the farmers adopt traditional beef fattening system for beef fattening target the cattle marketing during the Muslim festival "Eid-ul-Azha". Profitability margin equals BDT 13,350.84 per cattle. The benefit cost ratio of the entire enterprise was 0.52 that means cattle fattening enterprise is profitable and feasible business enterprise. The major problems facing the farmers include high cost of feeds, inadequate credit facilities, disease attack, illegal use of human drugs for cattle fattening, price fluctuation and inadequate extension services. A policy and research emphasis should be geared toward feeds production at affordable price to the fatteners and fatteners should be educated on how to formulate local feeds to reduce cost and access to feeds for better efficiency and discourage to use human drugs, tablets and injection for cattle fattening. These findings can be used by the Ministry of Livestock and Fisheries Development extension agents to promote beef cattle fattening in areas where beef cattle fattening is not practiced in the country.
\end{abstract}

Keywords: Economics Analysis, Beef cattle, Fattening, Profitability

\section{Introduction}

In Bangladesh, livestock is one of the most potential sub-sectors of agriculture which plays an indispensable role in promoting human health and national economy of the country. Large ruminants are cattle and buffalo and small ruminants are sheep and goat constitutes the major portion of livestock. The present population of livestock is 23.12 million cattle, 1.39 million buffalo, 24.15 million goat and 3.07 million sheep (DLS, 2010-11). Despite the large number of cattle available in the country, the contribution of the livestock sub-sector to the national economy is low. Cattle fattening helps to meet the rising demand for high-protein foods in the country and plays a great role in: (i) enhancing food security, (ii) providing households with employment, income, investment opportunity and a store of value, and (iii) providing draught power and manure for sustainable agriculture and (iv) cattle fulfilling cultural roles. The growing demands for ruminants' meats from city dwellers also present opportunities for fattening as well as improved markets for the animals. Fattening of animals is a highly profitable venture with return of premium to the farmer. Bangladesh is a low-lying densely populated country with more than 150 million people where about $75 \%$ live in rural areas and the rural poverty rate is $25.6 \%$, of which $12.4 \%$ are extreme (Hodson R. 2006 and the daily Prothom alo 2014). Northern Bangladesh is currently working hard to develop its agribusiness potential mainly cattle fattening. Cattle fattening mostly conducted through micro-credit activities, could form an appropriate tool for poverty alleviation and improvement in food security among the people ( Jean, 1993; Uza et al.,1999 and Maikasuwa et al.2012). However, the country's meat producers estimate that slaughterhouses need up to 3 million beef cattle every year to feed Bangladeshi appetites, and to help meet demand. More than 2 million beef cattle are smuggled from India to Bangladesh every year and most of the illegal trade takes place through the Indian border state of West Bengal. Farmers use rice straw of traditional varieties, green grass, sugarcane tops, wheat and rice bran, molasses, pulse bran and locally available resources such as vegetable by- products, rice gruel, 
boiled rice bran, oil cakes etc for cattle fattening. Use of urea molasses straw treatment in beef cattle resulted higher body weight, dressing percentage and also in better carcass quality than untreated straw. The acute shortage of feeds and fodder has long been identified as a serious constraint to optimum livestock production in Bangladesh (Saadullah,1995). During the holy Eid-Al Azha festival Muslims always goes for Kurbani (sacrificing slaughtered livestock). Animals including cows, goats, camels and sheep are slaughtered each year to mark the festival. Bangladeshi Muslims celebrate the Eid-ul-Azha in every year. About 1.8 million cattle are sacrificed within two or three days of this occasion each year (Sujan et. al., 2011). So, the demand for cattle especially beef cattle increases several times higher during the holy Eidul-Azha festival. The price of cattle is also increased in this time. Keeping this occasion in mind, a large number of poor people are involved in bull fattening just before 3 or 4 months of Eid-Ul-Azha, when they sell the animals at prices which results in high margin. A cattle farming is a way of rearing cattle for profitable production of meat. Cattle fattening package is a four-steps rearing programme of male and/or infertile female emaciated cattle for harvesting their compensatory growth within a period of 60 to 120 days. Collection of animals considering their body characteristics followed by de-worming and feeding for effectively up to achieve a considerable level of live weight gain and marketing them readily are the four major factors to make the fattening package profitable. It is relatively easy and profitable system of cattle rearing to reduce poverty, unemployment and generate income for the rural people. So far we are aware a few literatures are available regarding socioeconomic status of cattle fattening farmers in northern Bangladesh, Also, there are no documented studies in Pabna and Sirajgonj to show the profitability of beef fattening. This study is an attempt to investigate the profitability of cow fattening enterprise in the study area.

This study is therefore an attempt to examine the profitability associated with beef cattle fattening enterprises in Sirajgonj and Pabna districts, which are pioneered for cattle fattening of Bangladesh.

The specific objectives of this study are:

i) to assess the socio-economic characteristics of beef cattle fattening operators in the study area,

ii) to determine profitability of beef cattle fattening enterprises, and

iii) to identify the problems that affect profitability of beef cattle fattening enterprises

\section{Materials and Methods}

Study area: The study was done in two upazilas namely Sathia from Pabna district and Raigonj upazila from Sirajgonj district which are in the northern part of Bangladesh.

Survey design: This survey was conducted with the aid of a detailed structured questionnaire. From each upazila, three villages were randomly selected. From each village, about 20-30 households who were engaged in cattle fattening. A total of 150 households were interviewed taking 60 households from each Pabna and Sirajgonj districts.

Data collection: A structured questionnaire was prepared for required data collection. Information was collected from respondents through face to face interview. Just prior to data collection the objective of the study was clearly explained to the respondents. The data were basically taken regarding the farmers' sex, age, education, farm size, social status, supply in market, expenditure and household size as well as some factors associated with cattle fattening such as breed, source of fund, feeding and nutrition, deworming treatment, etc.

Data analysis technique: The following analytical techniques were used to achieve the objectives of the study. Descriptive statistics such as measures of central tendency like mean, percentages and frequency 
for first objectives. The cost benefit analysis is a useful tool in determining the profitability of a beef cattle fattening enterprise when the fixed cost can be calculated. The economic analyzed the determinants;

NM=TR-TC

(Rahman, et al., (2002)

Where,

NM = Net Margin;

$\mathrm{TR}=$ Total Return;

$\mathrm{TC}=$ Total Cost;

TC=TVC+TFC.

Where, $\mathrm{TVC}=$ Total Variable Cost

TFC = Total Fixed Cost

This was employed to assess profitability of the enterprise. The following variables were calculated, where;

a). Gross margin (GM) is the difference between the total revenue earned and the total variable cost incurred, GM = TR-TVC.

b). Variable cost (VC) is the cost that varies with changes in output; it is a function of output level. The variable cost includes transportation, labour cost and cost price of live cattle for wholesalers

c). Fixed Cost is the cost that does not vary with respect to output (land rent, tools and equipment).

d). Total cost is the total expenditure for beef fattening enterprise including addition of both variable and fixed costs TC $=$ TFC+TVC.

e). Total revenue (TR) is the total income realized on output produced that is, quantity sold multiplied by price per unit.

f). Net Revenue is the difference between the total revenue and the total cost.

g). Benefit cost ratio i.e. (BCR) is the total revenue divided by the total cost, $B C R=T R / T C$. When $B C R$ is greater than 1 , the business is profitable.

Multiple regression analysis: This has been used to study the relationship between inputs and output (Mshelia et al., 1991, Daniel et al., 2009 and Jimjel $Z$ et al., 2014). To determine the input-out relationships of most important variable on net margin. The Cobb-Douglas production function would be selected to estimate the contribution of key variables for the fattening process of beef cattle.

The specific of the Cobb-Dougglas production function for beef cattle farming was as follows;

$$
Y=a X_{1} b^{1} X_{2} b^{2} X_{3} b^{3} X_{4} b^{4} X_{5} b^{5} X_{6} b^{6} U_{i}
$$

It can be written in double logarithm function in linear forms as follows:

$$
\operatorname{Ln} Y=\operatorname{In} a+b_{1} \operatorname{In} X_{1}+b_{2} \operatorname{In} X_{2}+b_{3} \operatorname{In} X_{3}+b_{4} \operatorname{Ln} X_{4}+b_{5} \operatorname{Ln} X_{5}+b_{6} \operatorname{Ln} X_{6}+U_{i}
$$

Where:

$$
\begin{aligned}
& Y=\text { Weight Gain (Kg.) } \\
& X_{1}=\text { Feeds cost (Tk.) } \\
& X_{2}=\text { Medicine and veterinary service cost (Tk.) } \\
& X_{3}=\text { Labour cost (Tk.) } \\
& X_{4}=\text { Salts and oil cake (Tk.) } \\
& X_{5}=\text { Water (liters) } \\
& X_{6}=\text { Length of fattening (month) } \\
& b_{1}-----b_{6}=\text { Coefficients to be estimated; and } \\
& \text { Ui=Error term }
\end{aligned}
$$




\section{Results and Discussion}

Socio economics characteristics of the farmers: The socio-economic characteristics included age, educational qualification, years of experience, duration of fattening by respondents, types of cow preferred for fattening and number of animal fattened by the respondents at a time. Curry (1996) stated that in order to come up with recommendation for specific strategies of improved management of beef cattle and to predict the effect of improved production system on the livelihoods of livestock keepers, it is important to first understand the socio-economic factors driving household members to undertake this enterprise. Table 1 illustrates that more than one third $(36.7 \%)$ of the farmers were in the age category between $41-50$ years and followed by $26.7 \%$ in $31-40$ years age group, $17.3 \%$ in $50-60$ years group and $7.3 \%$ were above 60 years of age farmers of more involved in cattle farming in the study area. Of the farmers, $82 \%$ were male and $18 \%$ female.

Table 1. Socio-economic characteristics of cattle fattening farmers

\begin{tabular}{|c|c|c|c|}
\hline Parameters & Variables & Frequency $(n=150)$ & Percentage (\%) \\
\hline \multicolumn{4}{|l|}{ Age } \\
\hline & $21-30$ & 18 & 12.0 \\
\hline & $31-40$ & 40 & 26.7 \\
\hline & $41-50$ & 55 & 36.7 \\
\hline & $51-60$ & 26 & 17.3 \\
\hline & $>60$ & 11 & 7.3 \\
\hline \multicolumn{4}{|l|}{ Gender } \\
\hline & Male & 123 & 82.0 \\
\hline & Female & 27 & 18.0 \\
\hline \multicolumn{4}{|l|}{ Ethnic Origin } \\
\hline & Muslim & 113 & 75.3 \\
\hline & Hindu & 31 & 20.7 \\
\hline & Others & 6 & 4.0 \\
\hline \multicolumn{4}{|l|}{ Farming System } \\
\hline & Full time & 83 & 55.2 \\
\hline & Part time & 67 & 44.8 \\
\hline \multicolumn{4}{|l|}{ Educational status } \\
\hline & No formal education & 3 & 2.2 \\
\hline & Primary level & 70 & 46.7 \\
\hline & Secondary level & 23 & 15.6 \\
\hline & Higher secondary level & 17 & 11.1 \\
\hline & Graduate and above & 37 & 24.4 \\
\hline \multicolumn{4}{|c|}{ Experience (Years) } \\
\hline & $<5$ & 21 & 14.0 \\
\hline & $5-10$ & 65 & 43.3 \\
\hline & $11-16$ & 31 & 20.7 \\
\hline & $17-22$ & 26 & 17.3 \\
\hline & $>22$ & 7 & 4.7 \\
\hline \multicolumn{4}{|c|}{ Number of animal fattened } \\
\hline & $2-4$ & 50 & 33.3 \\
\hline & $5-6$ & 70 & 46.7 \\
\hline & $7-8$ & 30 & 20.0 \\
\hline \multicolumn{4}{|c|}{ Duration of fattening } \\
\hline \multirow[t]{4}{*}{ Duration (Months) } & $1-3$ & 37 & 24.4 \\
\hline & $4-6$ & 93 & 62.2 \\
\hline & $7-9$ & 13 & 8.9 \\
\hline & $9>$ & 7 & 4.4 \\
\hline
\end{tabular}

Source: Field survey, 2013

Cattle fatteners were well experienced in farming as well $14 \%$ had below 5 years experience, the highest participated farmers (47) was had experiences of 5-10 years in farming that mean 5-10 year experienced 
farmer was more engage in beef cattle fattening. Respondent fatteners were asked about the duration of fattening, about $24.4 \%$ said the duration is between 1 to 3 months, while $62.2 \%$ of them said they took 46 months to fatten their cattle. Five to six cattle were reared by about $47 \%$ farmers while large numbers is 7-8 animals were by only $20 \%$ farmers which more than one third of the sample had only $2-4$ animals. The average number of cattle they fatten at a time was 5 cattle. About $46.7 \%$ of the respondents had primary education, $15.6 \%$ respondents completed their secondary education, while $24.4 \%$ had up to graduate education. This shows that literate people are more involved in the fattening business.

Profitability analysis for beef cattle fattening: The result of the farm budgeting analysis revealed that the cost of cattle constitute two main components, as variable and fixed cost. Variable cost of fattening comprise of various inputs cost such as cost of calves, feeds, health care service, water and salt-lick (Mulla,1997), labour charges, commission, market toll etc. On the other hand, fixed cost covered depreciation on fixed capital and equipment such as durable drinkers, spade, wheel barrow, bucket and rakes. Table 2 reveals that purchase value of animal was the highest about $73.90 \%$, operating expenses accounting for about $98.47 \%$ of the total variable costs and $1.53 \%$ only fixed cost of production. Feeder cattle/calve is the most important input used in the fattening program which constituted the greatest cost component. The study reveals that the average cost of cattle purchasing was about BDT 19,138.76. The component of feed used in fattening includes hay, grass, ureamolasses, concentrated, gain, crop residuals, water etc. At the time of this study the average cost of feed for cattle fattening was BDT 3,980.86.

Table 2. Cost and income from beef cattle fattening (Per cattle)

\begin{tabular}{|c|c|c|c|}
\hline \multicolumn{2}{|l|}{ Return } & \multicolumn{2}{|l|}{ Cost } \\
\hline Line items & Amount (BDT) & Line items & Amount (BDT) \\
\hline Selling price of fattened beef cattle & $38698.33(98.60)$ & Variable Costs (VC) & \\
\hline Sales of manure & $549.28(1.40)$ & Purchase of cattle before fattening & $19,138.76(73.90)$ \\
\hline & & Feed & $3,980.86(15.37)$ \\
\hline & & Drug/vaccine/Veterinary cost & $752.63(2.91)$ \\
\hline & & Labour charges & $565.55(2.18)$ \\
\hline & & Ropes & $71.77(0.28)$ \\
\hline & & Toll given & $150.47(0.58)$ \\
\hline & & Commission & $500.83(1.93)$ \\
\hline & & Transportation & $143.54(0.55)$ \\
\hline & & Miscellaneous & $195.69(0.76)$ \\
\hline & & Total variable cost (TVC) & $25,500.10(98.47)$ \\
\hline & & Fixed Cost (Depreciation cost) & \\
\hline & & Feeders & $55.69(0.22)$ \\
\hline & & Drinkers & $35.69(0.14)$ \\
\hline & & Rakes & $9.57(0.04)$ \\
\hline & & Spade & $14.35(0.06)$ \\
\hline & & Tubewell & $103.00(0.40)$ \\
\hline & & Shade & $15.69(0.06)$ \\
\hline & & Bucket & $19.14(0.07)$ \\
\hline & & Land rent & $143.54(0.55)$ \\
\hline & & Total Fixed Cost (TFC) & $396.67(1.53)$ \\
\hline Total returns (TR) & $39247.61(100)$ & Total Cost (TC) $=$ TVC+TFC & $25,896.77(100)$ \\
\hline Net Margin, $\mathrm{NM}=\mathrm{T}$ & $13,350.84$ & & \\
\hline Ratic & & & \\
\hline
\end{tabular}

Note: Figures within the Parentheses indicate percentage of total

Source: Field Survey 2013

Drugs/vaccines are another important input used for cow fattening. Antibiotics are typically viewed as tool for improving the health status of cattle (Mckinley, and Parish, 2007). The common drugs/medicine that were administered to animals during the fattening program include invermectin injection, teramycin loxytetramycin L.A. injection, B Complex injection, multivitamin injection, vbarminth tabs and vitamix power. But now a day, some dishonest cattle farmer and trader used unauthorized tablets, injection, pill and chemicals for cattle fattening. The study reveals that the total cost of drugs and vaccines including veterinary services per beef cattle for an average of four months was BDT 752.63. The labour used for 
cattle fattening program including both family labour and hired labour. Since farmers fattened an average of five cows per batch, the average weekly cost of labour per head of cattle was estimated as BDT 141.39 and for four months, it is BDT 565.55. Fixed cost including depreciation cost of equipment which was used for cattle fattening including feeders, drinkers, rake, spade wheel, barrow, buckets and rental value of land. In the study, total fixed cost was BDT 396.67 which was lower than variable cost. Net margin earned by the farmer was BDT 13,350.84 per cattle. The benefit cost ratio of the cattle fattening enterprise was 0.52 . That means for every one BDT invested in cattle fattening BDT 0.52 was realized as net profit. The average return on every BDT invested in the beef cattle fattening business $(52 \%)$ is higher than the prevailing public and private manages $16-20 \%$, which implying that beef cattle fattening operators.

Regression coefficient analysis results for beef cattle fattening: The economic data collected at the study area were subjected to regression analysis, using functional forms (double-log linear) to determine the influence of independent variables on the weight gained by the cattle within the period under consideration. Based on economic and statistical reasons Cobb-Douglass equation was selected as the best fit. The regression analysis of the beef cattle fattening as shown in table 3 indicated their $\mathrm{R}^{2}$ values to be $87 \%$. That means variation in revenue obtained from fattening of cattle are being explained by the exogenous or independent variables $(\mathrm{X} 1 \ldots \ldots \ldots \ldots \ldots . . . \times 6)$. All their F-ratios are highly significant at $(P<0.01)$, confirming the significance of these variables in cattle fattening. Looking at the coefficients of cattle fattening in table 3 all except that of equipment had positive relationships with the farmers' revenue from fattening. That means, an increase in the cost of equipment had adverse effect on farmers' income. The influence of cost of equipment could be felt only after a long period of time since depreciation occurs very slowly with good maintenance. However, significant factors affecting cattle fattening were feeds and purchase price of animals which were both highly significant at $(P<0.01)$.

Table 3. Regression analysis results for comparative beef cattle fattening in study area

\begin{tabular}{|l|c|c|c|}
\hline Variable & Coefficient & Standard error & t-value \\
\hline Constant & 38342.92 & $1235.063^{*}$ & 4.813 \\
\hline X1 & 11.564 & $0.320^{* *}$ & 4.889 \\
\hline X2 & -0.338 & 1.150 & -0.294 \\
\hline X3 & 1.054 & 1.696 & 0.975 \\
\hline X4 & 0.572 & $0.180^{* *}$ & 3.171 \\
\hline X5 & 0.586 & 2.164 & 0.271 \\
\hline X6 & 1.077 & 2.690 & 0.400 \\
\hline $\mathbf{R}^{2}$ & $\mathbf{0 . 8 7 1 2}$ & & \\
\hline F & $\mathbf{2 3 . 6 7 3 ^ { * * }}$ & & \\
\hline
\end{tabular}

$\mathrm{N}: \mathrm{B}:{ }^{* *}$ Significant at $1 \%$ * Significant at $5 \%$

Similarly, Sumberg and Cassaday (2010) reported that cattle fattening is highly profitable because investment in them show much quicker even more than large ruminants.

Identified problems faced by beef fatteners: The problems faced by the fatteners in the study area shown in Table 4 shows that about $14.59 \%$ reported that there is a high cost in feeding the animals, $13.62 \%$ reported inadequate credit to improve their business, while The third highest problem was cattle theft as reported by about $13 \%$ of the respondents. About $11.87 \%$ of the respondents reported that disease as a threat to the business due to cross border cattle trade without veterinary check up in our country weak enforcement of policies, laws, regulations and standards has led to spread of diseases. Notably $11.67 \%$ reported price fluctuation as a factor that affects the profitability of the business because Indian businessmen were selling cattle on credit. Our businessmen make payment after selling the cattle in Bangladeshi market. About $9.73 \%$ of the respondents were of the opinion that higher transportation cost has been a problem affecting business because high toll charge in cattle market. They said that trucks carrying cattle from border areas to different places including Dhaka have to pay tolls at different 
places. Toll has to be paid to police while the truck crosses a district. Highway police has to be paid separately.

Table 4. Problems affecting beef cattle fattening as perceived by respondents

\begin{tabular}{|c|c|c|}
\hline Problems & No. of respondents & Percentage \\
\hline High cost of feeds & 75 & 14.59 \\
\hline Inadequate credit facilities & 70 & 13.62 \\
\hline Cattle theft & 63 & 12.26 \\
\hline Disease attack & 61 & 11.87 \\
\hline Price fluctuation & 60 & 11.67 \\
\hline Higher transportation cost & 50 & 9.73 \\
\hline Lack of extension services & 45 & 8.75 \\
\hline Shortage of cattle feed & 40 & 7.78 \\
\hline High cost of labour & 35 & 6.81 \\
\hline Use of human drugs for cattle fattening & 10 & 1.95 \\
\hline Lack of knowledge about fattening & 5 & 0.97 \\
\hline
\end{tabular}

Source: Field study 2013

The respondents mentioned, lack of extension service as reported by $8.75 \%$, Shortage of cattle feed by $7.78 \%$, high cost of labour about $7 \%$ and $0.97 \%$ reported lack of knowledge about fattening. High cost of feeds $(14.88 \%)$ and inadequate credit facilities $(13.90 \%)$ constituted the major problem to cattle fattening in the study area.Similarly, inadequate credit could be as a result of lack of collateral which has made it almost impossible for them to access of credit from the bank. The feed for livestock is a chronic problem for char dwellers. Ali and Anwar (1987) is corroborated by the finding of present study, shortage of animal feed was the greatest problem of the farmers for rearing cattle. Hashem et al. (1999) also reported that lack of training, lack of credit facilities, price variation in different markets, disorganized marketing system were the problems for beef fattening in Bangladesh. About $81 \%$ farmers had the problem of transporting cattle for in the study area.

Some unscrupulous cattle farmers are used human drugs to fatten up cattle ahead of the holy Eid-ulAzha but it is a cause serious health hazards and even an unusual death of the cattle. They used human drugs of steroid group like 'Decason' tablets of Dexa-methasone for cattle rapid fattening before the Eidul-Azha as earning windfall profit. Cattle traders also used steroid tablets and hormone injection for cattle fattening in order received high profit .It was harmful way of cattle fattening may cause death of the cattle after a certain time and meat consumption of cattle is also hazardous for human health. because farmers are fed cattle about 20-25 tablets and it creates unusual pressure on the kidney and different organs the drug slowly affects the normal circulation of urine of the animal, within few days the cattle looks fat when the urine comes to its whole body.

\section{Conclusion}

Cattle fattening enterprise is a potential and effective option for poor and extreme poor and gained prominence as an important agribusiness sector in Bangladesh. It gives the farmer year round work and provides them with extra income. From the findings of this study, net profit is BDT 13,350.84 per fattened cattle for the average duration of four months. This implies that the cattle fattening business is profitable and worth venturing as a source of year round income and play a vital role in poverty reduction, creation of self employment opportunities in rural areas and animal protein supply. A Beed cattle farming contributes directly to the increase in the domestic beef meat production and indirectly to the decrease in the beef cattle imports (smuggling), and also to the improvement in the farmers' income, especially in the char areas in Pabna and Sirajgong districts. There is no doubt the livestock sub-sector faces certain problems relating to high feed cost (75) which ranks highest. This implies that the small-scale cattle enterprises in the study area lack any access to formal credit facilities. Inadequate credit facilities (70) rank second, followed by cattle theft (63), price instability (60), disease incidence (61), transportation cost (50) and lack of extension services rank least (45) that affecting profitability of cattle fattening. The following recommendations are made on the results of the study; 
1. Cattle fattening was able to additional income and create employment for farm household members, especially the unemployed family members like housewife.

2. Cattle fattening entrepreneur should be enlighten on how to access credit in order to increase their capital base to expand their scale of production. Facilitate access to finance for cattle farmers by strengthening the savings and loan for further investment.

3. Effective beef cattle agribusiness strategies plan was improved char livelihood and alternative year round income sources. Govt. support services and establishment policy can enhancing small scale cattle farming transferred in to beef cattle sub-sector agribusiness and deliver market driven agro-food products.

4. To have dynamic public and private finance and investment programs that help to stimulate growth and expansion of the agribusiness of Cattle fattening sector of Bangladesh.

5. The major constraint for the participating households is to continue the cattle fattening borrowing loan with high interest rate from Banks, NGOs and MFTs, due to shortage of investment fund, farmer cannot utilized their opportunities. Govt. and other donor agencies can take initiative to develop beef cattle fattening enterprise in study areas. 6. To develop farmer association in the study areas for participatory beef cattle agribusiness through better utilization their land, abour, feed, cattle breeds, calves, technology and disease controlling technique Also need to linkage with meat processing industries

7. Provide training on beef fattening, seasonal credit support, information on fattening technology and suitable breed to char dweller for improving beef cattle productivity, especially in Pabna and Sirajgonj char areas

\section{References}

Ali, M.A. and Anwar, A.B.M.N. 1987 "Cattle problem confrontation in a union of Mymensingh". Bangladesh J. Exten. Educ., Vol.2, pp41-49

Curry, J. 1996. "Gender and livestock in African production systems, an Introduction". Journal of Human Ecology, vol. 24, pp149160

Daniel, J.D, Ja'afar-Furo,M.R., TashKalma, A.K and Ezekiel, C.S. 2009. "Economic of cotton production in the Southern part of Adamawa State Nigeria" International Journal of Crop Science, vol. 1 (1),pp75-76.

Hashem, M.A., Moniruzzaman, M., Akhter S. and Hossain,M.M. 1999. "Cattle fattening by rural farmers in different districts of Bangladesh" Bangladesh J. Anim. Sci., vol.28 (1-2), pp81-88

Hodson, R. 2006. "The Char Livelihood Programme, the story and strategy so far CLP Secretariat, RDA Campus, Bogra

Jean, P. 1930. "Animal production in the tropic and sub-tropic" First edition, Macmillian Press Ltd., London

Jimjel Z., Daniel J. D., Hyelkaya P. 2014. "Technical Efficiency Sheep Fattening in Gombi Local Government Area of Adamawa State" International Journal of Innovative Research \& Development. Vol 3 Issue 4 PP:97-102 www.ijird.com

Mckinley, B. and Parish, J. 2007. "Stoker cattle forum, Feed Additives Basics. Cattle Network Com.

Mulla,NI. (1997) "Marketing costs and Price Spread-Cattle Marketing in Haveri Cattle Market of Karnataka, Journal of Agricultural Marketing.(West Bengal, India)" vol.40. (2), pp42-47.

Saadullah, M. 1995. "Integrated farming system for rural poor (Livestock based)". Journal of Biological Sciences 3 (10): pp. 898-902.

Sujan, O.F., Siddque, M.A.B. and Karim, M.F. 2011. "Study on cattle fattening practices of some selected areas of Rangpur district in Bangladesh" Bangladesh Research Publications Journal. Vol. 5(2). pp 125-132.

Sumberg, J.E. and Cassaday, K. 2010. "Sheep and Goats in humid West Africa.-A Strategy for small ruminant development in Africa" FAO Corporate Document Repository.

Uza, D.V., Avibodo, S.O., Abubakar, A. and Ahmed, U.H. 1999. "Transferable technology for enhancing smallholder livestock production" Onairi Publisher Ltd., Makurdi.

Maikasuwa,M.A , Ala, M.A. Daouda M. 2012." Impact of "Irkoy Gomni"Micro-Credit on Poverty Alleviation among Cattle Fatteners in Kollo LGA of Tillabery region Niger Republic" American International Journal of Contemporary Research Vol. 2 (4), PP. $130-135$ 